\title{
Belief levels in sexual myths in women and effects of myths on sexual satisfaction
}

\author{
Şefik Gökce* and Dilşad Herkiloğlu \\ Department of Obstetrics and Gynecology, Yeni Yüzyil University Private Gaziosmanpaşa Hospital, Gaziosmanpaşa, Istanbul, Turkey
}

\begin{abstract}
Objective: Sexual myths can affect sexual satisfaction. In the present study, it was aimed to determine the belief rates and levels of sexual myths and the effects of this situation on sexual functions and satisfaction levels in women of sexually active ages.

Materials and Methods: A total of 60 sexually active married women between the ages of 18-50 who admitted to the Obstetrics and Gynecology Clinics of our hospital due to various reasons were included in the study. All participants were administered a 40-question Sexual Beliefs Scale and a 9-question Female Sexual Function Index questionnaire.

Results: A total of 47 (77.6\%) of women included in the study were under 35 years old, 13 (22.4\%) were 35 years and older. Sexual myths that were the most commonly considered to be true were "success is extremely important in sexuality" (69.0\%), "sex is good only with a simultaneous orgasm" (60.3\%), and "as long as the couples love each other, they know how to give pleasure in making love " (56.9\%). Mean total FSFI score $(\mathrm{p}=0.002)$, mean total FSFI sexual satisfaction score ( $\mathrm{p}=$ $0.03)$ and mean total FSFI discomfort score $(\mathrm{p}=0.015)$ were significantly higher in the age group under 35 than the age group of 35 and over.
\end{abstract}

Conclusion: According to the findings of our study, the belief rates of sexual myths are very high, and sexual myths can push people to unnecessary anxiety both in terms of general sexual health and during sexual intercourse, and can decrease the health and pleasure level of sex.

\section{Introduction}

Sexual health is defined as not only the absence of a sexual illness or dysfunction, but also sustaining a regular and satisfying life. It is known that sexual approaches and sexual information vary between societies. Especially in some socioeconomically developing societies, the fact that speech and communication is more limited in sexual issues leads to the widespread misinformation about this issue [1-4].

Sexual myth is a knowledge that individuals think or insist that it is true in sexual matters, but which has no scientific value, is exaggerated or false [5,6]. Sexual myths can negatively affect people's sexual health at various levels. The effect of sexual myths on sexual health may vary depending on many factors such as education level between societies and individuals, gender, age, family, social environment, written and visual media. In addition, some sexual myths may not affect a person's sexual life because they are related to social or sociological issues, but a significant part of myths can directly affect a person's sexual life [6-9].

The distribution of belief about sexual myths varies among individuals. Rates of belief about some myths may differ according to the location. Some myths are widely believed in some societies. Similarly, an individual may believe in many myths or may think that some myths are false. Due to this diversity and high number of sexual myths, it can be important to determine the appropriate approach to sexual myths. Various scales have been used to determine the level of belief about sexual myths [10-13].

Sexual myths can affect sexual satisfaction. Satisfaction with sexual life also depends on sexual health and sexual functions. Some scales have been formed to determine sexual functions and sexual health. Female Sexual Function Index (FSFI) is one of the commonly used scales [14-17].
In our study, it was aimed to determine rates and levels of belief about sexual myths in sexually active women using the Sexual Beliefs Scale and FSFI scale, and to investigate the effects of this situation on sexual functions and satisfaction levels.

\section{Materials and methods}

This study was approved by the local ethics committee and was planned prospectively. A signed and written approval form was received from each participant.

\section{Patients and questionnaires}

A total of 60 sexually active married women between the ages of 18-50, who applied to our hospital's Obstetrics and Gynecology Clinics for various reasons, were included in the study. All participants were administered a 40-question Sexual Beliefs Scale [18-20] and a 9-question Female Sexual Function Index [21,22] questionnaire. The answers on the Sexual Beliefs Scale were received and scored as "I have no idea" (0 points), "false" (1 point), "partially false / partially true" (2 points) and "true" ( 3 points). The individual total score was calculated to be 120 . In the FSFI questionnaire, the answers were received as "never", "rarely", "sometimes", "often" and "always" and scored between

${ }^{\star}$ Correspondence to: Şefik Gökce, Department of Obstetrics and Gynecology, Yeni Yüzyil University Private Gaziosmanpaşa Hospital, Gaziosmanpaşa, Istanbul, Turkey, Tel: +90-5458751050, Fax: +90-323653838; E-mail: sefgokce@gmail.com

Key words: sexual beliefs scale, sexual myths, Female Sexual Function Index (FSFI)

Received: March 04, 2020; Accepted: March 19, 2020; Published: March 23 2020 
1 and 5 points. The individual total score was calculated to be 45 . In the FSFI questionnaire, the questions were grouped as sexual satisfaction (3 questions: 15 points), frequency of libido and sexual intercourse (4 questions: 20 points), and discomfort during the relationship (2 questions: 10 points).

\section{Statistical analysis}

All statistical analysis in the study were done using SPSS 25.0 software (IBM SPSS, Chicago, IL, USA). Descriptive data are given as numbers and percentages. In terms of categorical variables, comparisons between groups were made with Pearson's Chi Square test and Fisher's Exact Test. Whether continuous variables are suitable for normal distribution was confirmed by the Kolmogorov-Smirnov Test. The differences between the groups in terms of continuous variables were made using Student's t Test and the comparison of mean values between multiple groups by variance analysis. The correlation between continuous variables was tested with Spearman's correlation analysis. The results were evaluated within the $95 \%$ confidence interval, and $\mathrm{p}<$ 0.05 values were considered significant. Bonferroni trueion was made where appropriate.

\section{Results}

The mean age of women included in the study was $29.5 \pm 7.6$ years (range: $18-50$ years). A total of 47 (77.6\%) of women were under 35 years old, $13(22.4 \%)$ were 35 years and older.

Sexual myths that were the most commonly considered to be true were "success is extremely important in sexuality" (69.0\%), "sex is good only with a simultaneous orgasm" (60.3\%), "as long as the couples love each other, they know how to give pleasure in making love " $(56.9 \%)$, "a good sex is increased excitement and orgasm" (\% 53.4) "making love must always be natural and spontaneous" (50.0\%). The myths that were the most commonly considered to be false were "Any woman who initiates sexual activity is immoral" (86.2\%), "The man who fails in the sexual intercourse is not a man" (77.6\%), "sexuality is only for men" (75.9\%), "thinking and talking about sexuality is a shame" $(70.7 \%)$, "Fantasy during intercourse is false, and is cheating" (67.2\%), "Sexual areas are dirty and should not be touched" (65.5\%) myths. The myths with highest number of the participants with no idea about were "hymen could be ruptured with dry humping" (22.4\%), "hymen could be ruptured with masturbation" (22.4\%), "masturbation is dirty and harmful" (20.7\%), "masturbation reduces desire and power" (20.7\%), "masturbation is a false behaviour during the sexual intercourse" (19.0\%) and "there are strict rules about what is normal in making love" (19.0\%) (Table 1).

There were no significant differences in terms of the mean age, the mean total FSFI score, the mean total FSFI sexual satisfaction score, the mean total FSFI libido score, and the mean total FSFI discomfort during sexual myths among the response distribution groups (groups of "no idea", "false", "partially true", and "true") ( $p>0.008$ for each according to Bonferroni trueion) (Table 2).

Mean total FSFI score $(p=0.002)$, mean total FSFI sexual satisfaction score $(\mathrm{p}=0.03)$ and mean total FSFI discomfort score $(\mathrm{p}=$ 0.015 ) were significantly higher in the age group under 35 than the age group of 35 and over (Table 3 ).

In correlation analysis of age and total sexual belief scale score ( $\mathrm{p}$ $=0.01, r=0.334$ ) were found to be significantly correlated. Age was found to be reversely correlated with FSFI score $(\mathrm{p}=0.034, \mathrm{r}=-0.279)$, total FSFI sexual satisfaction score $(\mathrm{p}=0.014, \mathrm{r}=-0.323)$ and total FSFI libido and relationship frequency score $(\mathrm{p}=0.021, \mathrm{r}=-0.127)$. Sexual belief scale total score and total FSFI sexual satisfaction score correlated significantly ( $\mathrm{p}=0.046, \mathrm{r}=-0.263)$ (Table 4).

No significant difference was found between the groups under 35 and over 35 in terms of response distribution regarding sexual myths ( $p>0.05$ for each).

There were no significant differences in terms of age distribution and belief about myths distribution between those who were considered to be a sexual dysfunction group with a total FSFI score below 30 points and those with a score above 30 ( $\mathrm{p}>0.008$ for each according to Bonferroni trueion).

A mean of $24.4 \%( \pm 16.5)$ of the 40 sexual myths included in the study were considered to be true by the participants, and a mean of $41.3 \%$ ( \pm 19.9 ) of the myths were considered to be false. There were only two participants who did not believe in any of the myths. The highest "myth believer" participant believed in $70 \%$ of the myths in the questionnaire.

\section{Discussion}

There have been numerous sexual myths in every society in the world. Sexual myths can negatively affect people's sexual health or quality of sexual life. It is important to determine the prevalence and belief levels of sexual myths on a social, regional, and individual basis $[6,10,12]$. In our study, the belief levels of 40 different sexual myths in women of reproductive age were questioned, and their effects on the quality of sexual life in women were examined.

Sexuality is seen as a taboo in some societies, which causes sexual myths to become more common. Sexual myths can cause low interpersonal communication, high expectations, various levels of fear and anxiety, and sexual dysfunction in some cases. For these reasons, it is important to reveal the findings scientifically by conducting extensive studies on data on sexual myths $[8,9,14]$. Therefore, the number of myths was kept very wide in our study.

It has been reported that sexual experience can reduce the belief about sexual myths [23]. Kilic et al. [23] reported that women with experience on sexual intercourse believed in fewer sexual myths than those without. Yasan et al. [24] stated that women with sexual partners believe fewer myths, and that sexual experience decreases myths, although a small amount, but that most myths continue despite sexual experience. Although all the participants included in our study were married, their belief about sexual myths was found to be high. These data show that sexual experiences are not enough to reduce the number and the level of belief on sexual myths, and rehabilitation or training programs should be done on this subject.

Some sexual myths are widely considered to be true $[20,23,25]$. Karabulutlu et al. [20] reported that the most common myths were "as long as the couples love each other, they know how to give pleasure in making love" (80\%), "sex is good only with a simultaneous orgasm" $(75 \%)$ and "erection is always a sign for desire" (65\%). Ejder-Apay et al. [19] reported the most common as; "as long as the couples love each other, they know how to give pleasure in making love" (76.2\%), "couples instinctively know the feelings and thinking of each other" (69.9\%), and "men are always passionate and ready for sexual intercourse" (65.9\%). In the present study, sexual myths that were the most commonly considered to be true were "success is extremely important in sexuality" (69.0\%), "sex is good only with a simultaneous orgasm" (60.3\%), "as long as the couples love each other, they know how to give pleasure in 
Table 1. Distribution of responses to sexual myths in the Sexual Beliefs Scale (\%)

\begin{tabular}{|c|c|c|c|c|}
\hline & No idea & False & Partially right & Right \\
\hline Success is extremely important in sexuality & 5.2 & 10.3 & 15.5 & 69.0 \\
\hline Sex is good only with a simultaneous orgasm & 6.9 & 17.2 & 15.5 & 60.3 \\
\hline As long as the couples love each other, they know how to give pleasure in making love & 3.4 & 6.9 & 32.8 & 56.9 \\
\hline A good love connotes to a constant sexual excitement and orgasm as a consequence & 12.1 & 6.9 & 27.6 & 53.4 \\
\hline Making love must always be natural and spontaneous & 3.4 & 8.6 & 37.9 & 50.0 \\
\hline Couples know what they think and want during the sexual intercourse & 8.6 & 17.2 & 29.3 & 44.8 \\
\hline Men desire the sexual intercourse all the time and they are always ready for this & 5.2 & 12.1 & 39.7 & 43.1 \\
\hline Making love requires erection & 5.2 & 13.8 & 39.7 & 41.4 \\
\hline No intercourse should be during menstruation and pregnancy & 10.3 & 20.7 & 27.6 & 41.4 \\
\hline Erection is always a sign of sexual desire and stimulation & 10.3 & 24.1 & 31.0 & 34.5 \\
\hline Every man should know how to give pleasure to every woman & 5.2 & 19.0 & 44.8 & 31.0 \\
\hline First sexual intercourse is difficult and painful for woman & 5.2 & 32.8 & 32.8 & 29.3 \\
\hline The size of male genitals is sexually important & 12.1 & 34.5 & 25.9 & 27.6 \\
\hline Oral sex is dirty & 15.5 & 41.4 & 17.2 & 25.9 \\
\hline The man should manage the sexual intercourse & 6.9 & 43.1 & 25.9 & 24.1 \\
\hline Sexuality means sexual intercourse & 3.4 & 43.1 & 31.0 & 22.4 \\
\hline Mature woman must have orgasm with intercourse & 12.1 & 36.2 & 31.0 & 20.7 \\
\hline Masturbation is a false behavior during the sexual intercourse & 19 & 32.8 & 29.3 & 19.0 \\
\hline Should ejaculate immediately after erection & 17.2 & 44.8 & 19.0 & 19.0 \\
\hline The most natural position for the sexual intercourse is man-on-top position & 6.9 & 48.3 & 25.9 & 19.0 \\
\hline Men interests in orgasm, women in emotion & 10.3 & 44.8 & 25.9 & 19.0 \\
\hline Neither men nor women can refuse sexual intercourse & 8.6 & 36.2 & 37.9 & 17.2 \\
\hline Masturbation reduces desire and power & 20.7 & 39.7 & 22.4 & 17.2 \\
\hline Sexual activity must be initiated by the man & 5.2 & 51.7 & 27.6 & 15.5 \\
\hline Loss of erection on a man's penis means that he does not find his partner attractive & 8.6 & 53.4 & 22.4 & 15.5 \\
\hline Making love has some certain and explicit rules & 19 & 48.3 & 17.2 & 15.5 \\
\hline Sexual areas are dirty and should not be touched & 5.2 & 65.5 & 13.8 & 15.5 \\
\hline Men should not show their emotions & 6.9 & 60.3 & 19.0 & 13.8 \\
\hline It is difficult for the penis to enter the vagina & 10.3 & 37.9 & 37.9 & 13.8 \\
\hline Fantasy during intercourse is false, and is cheating & 5.2 & 67.2 & 13.8 & 13.8 \\
\hline Hymen could be ruptured with masturbation & 22.4 & 53.4 & 12.1 & 12.1 \\
\hline Getting close should end with sex & 5.2 & 53.4 & 31.0 & 10.3 \\
\hline Strong men are able to make love for a few times successively & 12.1 & 51.7 & 25.9 & 10.3 \\
\hline No virginity if there is not blood in the first sexual intercourse & 6.9 & 63.8 & 19.0 & 10.3 \\
\hline Hymen could be ruptured with dry humping & 22.4 & 46.6 & 20.7 & 10.3 \\
\hline Thinking or talking sexuality is a shame & 12.1 & 70.7 & 8.6 & 8.6 \\
\hline The man who fails in the sexual intercourse is not a man & 5.2 & 77.6 & 10.3 & 6.9 \\
\hline Masturbation is dirty and harmful & 20.7 & 51.7 & 20.7 & 6.9 \\
\hline Sexuality is only for men & 10.3 & 75.9 & 6.9 & 6.9 \\
\hline Any woman who initiates sexual activity is immoral & 6.9 & 86.2 & 5.2 & 1.7 \\
\hline
\end{tabular}

making love " (56.9\%), "a good sex is increased excitement and orgasm" (53.4\%) "making love must always be natural and spontaneous" (50.0\%).

Success in sexual intercourse is a sign of power in many societies and individuals. The necessity to be successful in sexual intercourse is a widely accepted myth $[19,23,25]$. In our study, the myth of "success is extremely important in sexuality" was accepted as true by $69.0 \%$ of the participants. This finding shows the importance of being successful during the sexual intercourse in the society.

One of the common myths is that the sexual intercourse should result in simultaneous orgasm $[19,26]$. Aygin et al. [26] reported the rate of women believing in this myth as $69.9 \%$. Ejder-Apay et al. [19] reported the rate of those who believe in myth that "having orgasm at the same time is the most important target" as $46.2 \%$. In our study, the rate of considering this myth as true was found to be $60.3 \%$. In addition, we found that the myth that "a good sex is increased excitement and orgasm" was accepted as true with a high rate as $53.4 \%$. These data show that the main goal in the sexual intercourse is thought to be having orgasms at the same time.
Being in expectation from the partner during sexual life and intercourse is known to be common in the society $[19,23,26]$. The rates of believing in the myth that "as long as the couples love each other, they know how to give pleasure in making love" was reported as $86.6 \%$ by Aygin et al. [26], as $94.2 \%$ by Özsoy et al. [27], as $83.9 \%$ by Kilic et al. [23], and as $85.9 \%$ by Uyar et al. [28]. In addition, the rate of belief of the myth that "every man should know how to give pleasure to every woman" was reported as $92.4 \%$ by Aygin et al. [26], as $65.7 \%$ by Ejder-Apay et al. [19], as $77.8 \%$ by Torun et al. [29], and as $80.2 \%$ by Özsoy et al. [27]. In our study, the rates of believing in the myth that "as long as the couples love each other, they know how to give pleasure in making love" and "every man should know how to give pleasure to every woman" were found to be as $56.9 \%$ and $31.0 \%$, respectively. These data show that a significant rate of women believe that their partners or husbands should know how to give pleasure.

Beliefs that give men a dominant role during sexual intercourse are common in some societies $[8,9,19,26]$. Aygin et al. [26] reported that the rates of women who believe that men are always passionate 
Table 2. Comparison of responses to sexual myths in the Sexual Beliefs Scale by age and FSFI scores ( $\mathrm{p}$ values). * According to Bonferroni trueion, $\mathrm{p}<0.008$ values were considered significant.

\begin{tabular}{|c|c|c|c|c|c|}
\hline Sexual myths & Age & $\begin{array}{l}\text { According to } \\
\text { total FSFI score }\end{array}$ & $\begin{array}{l}\text { According to } \\
\text { total FSFI libido } \\
\text { score }\end{array}$ & $\begin{array}{l}\text { FSFI Sexual } \\
\text { satisfaction total }\end{array}$ & $\begin{array}{l}\text { According to } \\
\text { discomfort } \\
\text { during total } \\
\text { FSFI intercourse }\end{array}$ \\
\hline Men should not show their emotions & 0.164 & 0.126 & 0.092 & 0.100 & 0.453 \\
\hline Success is extremely important in sexuality & 0.362 & 0.595 & 0.539 & 0.295 & 0.805 \\
\hline Sexual activity must be initiated by the man & 0.260 & 0.597 & 0.646 & 0.479 & 0.68 \\
\hline Men are always passionate and ready for sexual intercourse & 0.274 & 0.022 & 0.058 & 0.006 & 0.103 \\
\hline Getting close should end with sex & 0.655 & 0.642 & 0.698 & 0.252 & 0.807 \\
\hline $\begin{array}{l}\text { Any woman who initiates } \\
\text { sexual activity is immoral }\end{array}$ & 0.916 & 0.623 & 0.717 & 0.612 & 0.507 \\
\hline Sevişmek cinsel birleşme demektir (Sexuality means sexual intercourse) & 0.739 & 0.639 & 0.669 & 0.743 & 0.557 \\
\hline Making love requires an erection & 0.964 & 0.949 & 0.916 & 0.765 & 0.728 \\
\hline A good sex is increased excitement and orgasm & 0.508 & 0.304 & 0.565 & 0.065 & 0.508 \\
\hline The man should manage the sexual intercourse & 0.160 & 0.234 & 0.128 & 0.254 & 0.534 \\
\hline Thinking or talking sexuality is a shame & 0.942 & 0.969 & 0.678 & 0.999 & 0.652 \\
\hline Making love must always be natural and spontaneous & 0.409 & 0.619 & 0.793 & 0.366 & 0.642 \\
\hline Every man should know how to give pleasure to every woman & 0.500 & 0.684 & 0.420 & 0.720 & 0.615 \\
\hline Sex is good only with a simultaneous orgasm & 0.143 & 0.350 & 0.374 & 0.417 & 0.196 \\
\hline Couples instinctively know the feelings and thinking of each other & 0.433 & 0.363 & 0.313 & 0.156 & 0.677 \\
\hline As long as the couples love each other, they know how to give pleasure in making love & 0.580 & 0.861 & 0.600 & 0.662 & 0.985 \\
\hline Masturbation is false during intercourse & 0.303 & 0.793 & 0.771 & 0.715 & 0.845 \\
\hline Loss of erection on a man's penis means that he does not find his partner attractive & 0.432 & 0.089 & 0.075 & 0.043 & 0.309 \\
\hline Man and woman cannot reject sexual intercourse & 0.212 & 0.962 & 0.979 & 0.964 & 0.837 \\
\hline There are strict rules about what is normal in making love & 0.133 & 0.376 & 0.621 & 0.264 & 0.345 \\
\hline Mature woman must have orgasm with intercourse & 0.176 & 0.440 & 0.588 & 0.160 & 0.722 \\
\hline Man is powerful if he can have sex one after another & 0.179 & 0.630 & 0.481 & 0.756 & 0.752 \\
\hline Penis size is important and gives pleasure & 0.385 & 0.878 & 0.849 & 0.978 & 0.645 \\
\hline It is difficult for the penis to enter the vagina & 0.834 & 0.983 & 0.953 & 0.954 & 0.783 \\
\hline First sexual intercourse is difficult and painful for woman & 0.254 & 0.633 & 0.955 & 0.331 & 0.347 \\
\hline No virginity if there is not blood in the first sexual intercourse & 0.683 & 0.653 & 0.661 & 0.469 & 0.858 \\
\hline The man who fails the first sexual intercourse is not a man & 0.365 & 0.468 & 0.606 & 0.100 & 0.927 \\
\hline Hymen could be ruptured with dry humping & 0.381 & 0.970 & 0.960 & 0.846 & 0.566 \\
\hline Hymen could be ruptured with masturbation & 0.287 & 0.992 & 0.958 & 0.949 & 0.995 \\
\hline Should ejaculate immediately after erection & 0.226 & 0.699 & 0.389 & 0.948 & 0.76 \\
\hline Masturbation is dirty and harmful & 0.853 & 0.320 & 0.357 & 0.485 & 0.21 \\
\hline Oral sex is dirty & 0.638 & 0.068 & 0.035 & 0.153 & 0.186 \\
\hline Fantasy during intercourse is false, and is cheating & 0.630 & 0.166 & 0.111 & 0.239 & 0.31 \\
\hline No intercourse should be during menstruation and pregnancy & 0.778 & 0.865 & 0.862 & 0.894 & 0.872 \\
\hline The most natural way is man-on-top & 0.320 & 0.769 & 0.992 & 0.686 & 0.279 \\
\hline Men interests in orgasm, women in emotion & 0.132 & 0.012 & 0.010 & 0.012 & 0.062 \\
\hline Sexual areas are dirty and should not be touched & 0.411 & 0.024 & 0.017 & 0.048 & 0.062 \\
\hline Sexuality is only for men & 0.986 & 0.944 & 0.984 & 0.606 & 0.941 \\
\hline Erection is always a sign for desire & 0.252 & 0.535 & 0.383 & 0.485 & 0.846 \\
\hline Masturbation reduces desire and power & 0.131 & 0.327 & 0.368 & 0.224 & 0.598 \\
\hline
\end{tabular}

Table 3. Mean values of the Female Sexual Function Index (FSFI) scores by age groups. SD: Standard Deviation; FSFI: Female Sexual Function Index.

\begin{tabular}{|c|c|c|c|c|c|c|c|}
\hline & \multicolumn{2}{|c|}{$<35$ years } & \multicolumn{2}{|c|}{35 years and above } & \multicolumn{2}{|c|}{ General } & \multirow{2}{*}{$\mathbf{p}$} \\
\hline & Mean & SD & Mean & SD & Mean & SD & \\
\hline FSFI total & 25.9 & 9.5 & 17.0 & 16.1 & 23.9 & 11.7 & 0.002 \\
\hline FSFI sexual satisfaction total & 9.6 & 3.6 & 5.5 & 5.5 & 8.7 & 4.4 & $\mathbf{0 . 0 3}$ \\
\hline FSFI libido and frequency total & 10.4 & 3.8 & 7.2 & 6.5 & 9.6 & 4.7 & 0.131 \\
\hline FSFI discomfort during sexual intercourse & 5.9 & 3.0 & 4.3 & 4.3 & 5.6 & 3.4 & 0.015 \\
\hline
\end{tabular}

and ready for sexual intercourse, that a man cannot reject sexual intercourse, and that initiating and controlling the process of sexuality is the duty of the men were $73.9 \%, 68.8 \%$, and $30.6 \%$, respectively. Ejder-Apay et al. [19] reported the rate of belief about the myth that "men are always passionate and ready for sexual intercourse" as $66.2 \%$. In our study, the myths that "men are always passionate and ready for sexual intercourse", "the man should manage the sexual intercourse", and "the most natural way is man-on-top" were considered to be true by $43.1 \%, 24.1 \%$, and $19.0 \%$ of the participants, respectively. These data show that a man is given a managerial role in the sexual intercourse.

There is a association between erection and the role given to a man in sexual life. Therefore, there are some common beliefs about erection $[19,26,27]$. Aygin et al. [26] reported that $70.1 \%$ of women believe that 
Table 4. Correlation analysis between age, Sexual Beliefs Scale and Female Sexual Function Index (FSFI) scores. SBS: Sexual Beliefs Scale; FSFI: Female Sexual Function Index.

\begin{tabular}{|l|c|c|c|}
\hline & & Age & SBS total \\
\hline SBS total & $\mathrm{r}$ & $0.334^{*}$ & \\
\hline FSFI total & $\mathrm{p}$ & $\mathbf{0 . 0 1 0}$ & \\
\hline & $\mathrm{r}$ & $-0.279^{*}$ & -0.211 \\
\hline FSFI sexual satisfaction total & $\mathrm{p}$ & $\mathbf{0 . 0 3 4}$ & 0.113 \\
\hline & $\mathrm{r}$ & $-0.323^{*}$ & $-0.263^{*}$ \\
\hline FSFI dibido and frequency total & $\mathrm{p}$ & $\mathbf{0 . 0 1 4}$ & $\mathbf{0 . 0 4 6}$ \\
\hline & $\mathrm{r}$ & $-0.304^{*}$ & -0.241 \\
\hline FSFI discomfort during sexual intercourse & $\mathrm{p}$ & $\mathbf{0 . 0 2 1}$ & 0.071 \\
\hline & $\mathrm{r}$ & -0.127 & -0.075 \\
\hline
\end{tabular}

it is bad to have an orgasm immediately after an erection in men. The rate of belief about the myth of "erection always indicates sexual desire" were reported as $59.6 \%$ by Ejder-Apay et al. [19], and as $76.7 \%$ by Özsoy et al. [27]. The rate of the belief about the myth that "erection is the key to good sexual intercourse" was reported as $38.5 \%$ by Ejder-Apay et al. [19], and as $44.2 \%$ by Özsoy et al. [27]. Özsoy et al. [27] reported the rate of believing in the myth of "loss of erection on a man's penis means that he does not find his partner attractive" as $43 \%$. In our study, the believing rates in the myths of "making love requires erection", "erection is always a sign of sexual desire and stimulation", and "a man should ejaculate immediately after erection" were found as $41.4 \%, 34.5 \%$, and $19.0 \%$, respectively. These data show that there are fixed thoughts that are widely accepted in the society between sexual life and erection.

Lack of information about masturbation is common [19,23,26-30]. The rate of belief about the myth of "masturbation is dirty and harmful in women" was reported as 35\% by Aygin et al. [26], as 33.3\% by EjderApay et al. [19], and as $43 \%$ by Özsoy et al. [27]. The rate of belief about "masturbation is false during sexual intercourse" is found as $63.1 \%$ by Aygin et al. [26], as $46.4 \%$ by Ejder-Apay et al. [19], as $48.8 \%$ by Özsoy et al. [27], and as $41.2 \%$ by Kilic et al. [23]. Eris-Davul et al. [30] found that the myth of "masturbation is dirty and harmful" was believed in higher rates in rural areas. These researchers also reported that female participants were less masturbating, which may be due to the myth that "masturbation is harmful for women" [30]. In our study, the myth that "masturbation is dirty and harmful" was the least believed myth. In addition, the myths that "masturbation is false", "masturbation reduces desire and power", and "the hymen could be damaged with masturbation" were not commonly believed, however, the rate of the women who had no idea about these myths was high. These data show that false or incomplete information about masturbation is common.

There are many differences amongst the societies in terms of belief about myths. While some myths are widely accepted in some societies, the same myths may not have taken place in other societies $[8,9,19,23]$. Ejder-Apay et al. [19] reported the least-commonly myths as "the man who fails in the first sexual intercourse is not a man", "getting close should end with sex", "men should not show their emotions", "any woman who initiates sexual activity is immoral", and "sexuality is only for men". Kilic et al. [23] determined the least-commonly myths as "women's sexual desire is low", "fantasy during intercourse is false, and is cheating", and "any woman who initiates sexual activity is immoral". In the present study, the myths that were the most commonly accepted to be false were "any woman who initiates sexual activity is immoral", "the man who fails in the first sexual intercourse is not a man", "sexuality is only for men", "thinking or talking sexuality is a shame", "fantasy during intercourse is false, and is cheating", and "sexual areas are dirty and should not be touched". These data show that some myths are about to be abandoned in society. According to these findings, the opinion of the society on myths can change, and it may be beneficial to work on this issue.

In some cases, a woman cannot make a final decision about some sexual myths due to various reasons. Women may not have a clear idea that some myths are true or false. In addition, there may be women who have no idea about some of the myths $[19,23,26]$. In our study, The myths with highest number of the participants with no idea about were "hymen could be ruptured with dry humping" (22.4\%), "hymen could be ruptured with masturbation" (22.4\%), "masturbation is dirty and harmful" (20.7\%), "masturbation reduces desire and power" (20.7\%), and "masturbation is a false behavior during the sexual intercourse" (19.0\%). It is noteworthy that these myths, which the women have the least information about, are mostly related to hymen and/or masturbation. The lack of information on these two issues may be attributed to the very limited level of sexual issues in the family and the community and the fact that sexual education has not been given before adulthood.

It has been stated that as the age increases in women, knowledge and experience about sexuality increase and belief about sexual myths may decrease. However, contrary to this, it has been also stated that the education level increases as the generation changes, and that young women can reach more accurate information on sexual issues $[23,26,28]$. Kilic et al. [23] reported that the rate of sexual myth belief decreased with age. Uyar et al. [28] and Aygin et al. [26] could not find an association between age and belief about myths. In our study, a positive correlation was found between age and total Sexual Beliefs Scale scores. This finding shows that as age increases with women, sexual myths and the level of belief about these myths increase. This situation may be attributed to the facts that sexual issues are spoken more widely in the society as the generations change, that the information is more easily accessible, and that the sexual education is changing.

In our study, a significant negative correlation was found between age and total FSFI libido and frequency of sexual intercourse scores. This finding shows that as the age increases, the desire and frequency of sexual intercourse decreases. This may be due to many factors such as long duration of marriage, or the number of children increased with age, both of that are not evaluated within the scope of our study. Nevertheless, it is expected that the level of libido and frequency of intercourse may be high at the young ages.

In our study, a significant negative correlation was found between age and total FSFI sexual satisfaction score. It was also found that the mean total sexual satisfaction score was higher in the group below 35 years of age. These findings show that as age increases, sexual satisfaction decreases. When this finding is analysed by combining it with the others, it is seen that increase in age is correlated with increased myths, decreased libido, and decreased sexual satisfaction.

In our study, no significant difference was found in terms of mean total libido and frequency of sexual intercourse among the groups formed according to the belief about sexual myths. In addition, no correlation was found between the total Sexual Belief Scale score and the total FSFI libido score. These data show that the presence or level of belief in sexual myths does not directly affect the level of libido and frequency of sexual intercourse in women.

In our study, no significant difference was found in terms of mean total FSFI sexual satisfaction score amongst the myth-belief groups. However, a correlation was found between the total Sexual Belief Scale score and the total FSFI sexual satisfaction score. This finding shows 
that the presence or level of belief in sexual myths reduces sexual satisfaction.

In our study, no significant difference was found in terms of the mean total FSFI discomfort during sexual intercourse score amongst the myth-belief groups. In addition, no correlation was found between the total Sexual Belief Scale score and the total FSFI discomfort score. These data show that the presence or level of belief in sexual myths does not directly affect the level of libido and frequency of sexual intercourse in women. This can be attributed to the fact that the feeling of discomfort in sexual intercourse is not related to a belief, and that this feeling has to do with a concrete pain or vaginal dryness during intercourse.

In our study, women with a total FSFI score below 30 were considered a sexual dysfunction group. No significant difference was found between those with and without sexual dysfunction in terms of belief status distribution to sexual myths. Although this finding shows that the myths do not have a direct effect on issues such as sexual desire, sexual intercourse frequency and sexual satisfaction in general, it may be more accurate to analyse the myths and these situations individually and in detail, rather than in general.

\section{Strengths and weaknesses}

There were some limitations in our study. Since the study was aimed to focus only on the sexual myths; the duration of marriage, number of children and education levels of women were not questioned in the questionnaires. Therefore, it was not possible to analyse whether some data were related to these factors. In our study, the myths that may have a direct impact on women's sexual life were also examined, and topics such as homosexuality, rape, group sex and HIV infection, which may be relatively distant from this issue, were not included in the questionnaires.

\section{Conclusion}

According to the findings of our study, the belief rates of sexual myths are very high, and sexual myths can push people to unnecessary anxiety both in terms of general sexual health and during sexual intercourse, and can decrease the health and pleasure level of sex. For these reasons, studies and programs should be carried out in order to raise the awareness of the society on the right information about sexual life and sexual relations.

\section{References}

1. Rao TS, Nagaraj AK (2015) Female sexuality. Indian J Psychiatry 57: S296-S302. [Crossref]

2. Ventriglio A, Bhugra D (2019) Sexuality in the 21st Century: Sexual Fluidity. East Asian Arch Psychiatry 29: 30-34. [Crossref]

3. Kapoor E, Kling JM, Kingsberg SA, Faubion SS (2018) Sexual Health in Women. $J$ Womens Health (Larchmt) 27: 1082-1085.

4. Rohleder P, Flowers P (2018) Towards a psychology of sexual health. J Health Psychol 23: 143-147. [Crossref]

5. Nobre PJ, Pinto Gouveia J, Gomes FA (2003) Sexual dysfunctional beliefs questionnaire: An instrument to assess sexual dysfunctional beliefs as vulnerability factors to sexual problems. Sex Relation Therapy 18: 171-204.

6. Grzanka PR, Zeiders KH, Miles JR (2016) Beyond "born this way?" reconsidering sexual orientation beliefs and attitudes. J Couns Psychol 63: 67-75. [Crossref]
7. Atallah S, Johnson-Agbakwu C, Rosenbaum T, Abdo C, Byers ES, et al. (2016) Ethical and Sociocultural Aspects of Sexual Function and Dysfunction in Both Sexes. $J$ Sex Med 13: 591-606. [Crossref]

8. Abdolmanafi A, Nobre P, Winter S, Tilley PJM, Jahromi RG (2018) Culture and Sexuality: Cognitive-Emotional Determinants of Sexual Dissatisfaction Among Iranian and New Zealand Women. J Sex Med 15: 687-697. [Crossref]

9. Alomair N, Alageel S, Davies N, Bailey JV (2020) Factors influencing sexual and reproductive health of Muslim women: a systematic review. Reprod Health 17: 33.

10. Katz-Wise SL, Hyde JS (2015) Sexual Fluidity and Related Attitudes and Beliefs Among Young Adults with a Same-Gender Orientation. Arch Sex Behav 44: 145914570. [Crossref]

11. McCauley E (2017) Challenges in educating patients and parents about differences in sex development. Am J Med Genet C Semin Med Genet 175: 293-299.

12. Arousell J, Carlbom A (2016) Culture and religious beliefs in relation to reproductive health. Best Pract Res Clin Obstet Gynaecol 32: 77-87. [Crossref]

13. Ören B, Zengin N, Yazici S, Akinci AC (2018) Attitudes, beliefs and comfort levels of midwifery students regarding sexual counselling in Turkey. Midwifery 56: 152-157. [Crossref]

14. Kouta C, Tolma EL (2008) Sexuality, sexual and reproductive health: an exploration of the knowledge, attitudes and beliefs of the Greek-Cypriot adolescents. Promot Educ 15: 24-31. [Crossref]

15. Leonardi-Warren K, Neff I, Mancuso M, Wenger B, Galbraith M, et al. (2016) Sexua Health: Exploring Patient Needs and Healthcare Provider Comfort and Knowledge. Clin J Oncol Nurs 20: E162-E167. [Crossref]

16. Zachariou A, Filiponi M, Kirana PS (2017) Translation and validation of the Greek version of the female sexual function index questionnaire. Int J Impot Res 29: 171-174. [Crossref]

17. Neijenhuijs KI, Hooghiemstra N, Holtmaat K, Aaronson NK, Groenvold M, et al. (2019) The Female Sexual Function Index (FSFI)-A Systematic review of measurement properties. $J$ Sex Med 16: 640-660. [Crossref]

18. Gölbasi Z, Evcili F, Eroglu K, Bircan H (2016) Sexual Myths Scale (SMS): Development, validity and reliability in Turkey. Sex Disabil 34: 75-87.

19. Apay SE, Nagorska M, Akpinar RB, Çelik AS, Binkowska-Bury M (2013) Student comparison of sexual myths: two-country case. Sex Disabil 31: 249-262.

20. Karabulutlu Ö, Yilmaz D (2018) Sexual myths among university students by gender STED 27: 155-164.

21. Yildiz H, Pinar R (2004) Sexual dysfunction in patients with myocardial infarction Anadolu Kardiyol Derg 4: 309-317. [Crossref]

22. Yilmaz CA, Eryilmaz HY (2004) Kadin cinsel fonksiyon sorgulama indeksinin (IFSF) geçerlik- güvenirlik çalişmasi. Androloji Bülteni 18: 275-276.

23. Kilci S, Özsoy S (2019) Premarital couples' belief in sexual myths and the factors that affect them. Kadin Sagligi ve Hemsireligi Dergisi 5: 1-28.

24. Yaşan A, Gürgen F (2004) The ways to get sexual knowledge and the comparison of the rate of sexual myths in nurses who have sexual partners and who do not have. Yeni Symposium 42: 72-76.

25. Kasaeian A, Weidenauer C, Hautzinger M, Randler C (2019) Reproductive success, relationship orientation, and sexual behavior in heterosexuals: relationship with chronotype, sleep, and sex. Evol Psychol 17: 1474704919859760. [Crossref]

26. Aygin A, Acil H, Yaman Ö, Celik Yilmaz A (2017) Female university students' opinions related to sexual myths. Androl Bul 19: 44-49.

27. Özsoy S, Bulut S (2017) The Effects of the sexual health information course on the sexuality myths of nursing students. KASHED 3: 54-67.

28. Uyar Ekmen B, Özkan M, Gül T (2017) Level of belief about sexual myths women with infertility treatment. Klinik Psikiyatri 20: 209-217.

29. Torun F, Torun SD, Özaydin AN (2011) Men's belief in sexual myths and factors effecting these myths. J Psychiatry Neurolo Sci 24: 24-31.

30. Eriş Davul Ö, Ertekin Yazici A (2019) Impact of university life on sexual attitudes and sexual myths. Cukurova Med J 44: 1432-1441.

Copyright: (C2020 Gökce S. This is an open-access article distributed under the terms of the Creative Commons Attribution License, which permits unrestricted use, distribution, and reproduction in any medium, provided the original author and source are credited. 